\title{
Potensi Ekstrak Daun Binahong (Anredera cordifolia) Sebagai Penghambat Bakteri Vibrio harveyi
}

\author{
Gde Raka Angga Kartika ${ }^{a *}$, Sri Andayani ${ }^{b}$, Soelistyowati ${ }^{\mathrm{b}}$ \\ ${ }^{a}$ Program Studi Manajemen Sumberdaya Perairan, Fakultas Kelautan dan Perikanan, Universitas Udayana, Kampus Bukit Jimbaran, Bali 80361, \\ Indonesia \\ ${ }^{b}$ Program Studi Budidaya Perairan, Fakultas Perikanan dan Kelautan, Universitas Brawijaya, Jalan Veteran, Malang, Jawa Timur 65113, Indonesia \\ * Penulis koresponden. Tel.: +62-993-931-223 \\ Alamate-mail: raka.angga@unud.ac.id
}

Diterima (received) 10 Mei 2016; disetujui (accepted) 27 Juni 2016; tersedia secara online (available online) 2 Agustus 2016

\begin{abstract}
Binahong (Anredera cordifolia) is a plant that can treat various kinds of diseases, because this plant has a high antioxidant content and as an antibacterial and antiviral. Vibriosis disease caused by the bacterium Vibrio harveyi is a serious problem in marine and brackish culture, this disease can cause death for shrimp and fish that farmed in marine or brackish. This study aims to determine the potential of using leaf extract Binahong with different concentrations as Vibrio harveyi inhibiting bacterial growth in vitro. The method used is to test the Minimum inhibitory concentration (MIC) to determine minimum levels inhibit the growth of Vibrio harveyi and Minimum Bactericidal Concentration (MBC) using paper disc. The results showed the use of leaf extract Binahong (Anredera cordifolia) with different concentrations significant effect on the growth of Vibrio harveyi in vitro. Binahong leaf extract (Anredera cordifolia) with a concentration of $3 \%, 5 \%, 7 \%, 9 \%, 11 \%$ and $13 \%$ is only bacteriostatic which inhibits the growth of bacteria Vibrio harveyi with the best concentration obtained is equal to $13 \%$.
\end{abstract}

Keywords: Binahong leaves; Vibrio harveyi; inhibition

\begin{abstract}
Abstrak
Binahong merupakan salah satu tanaman yang dapat mengobati berbagai jenis penyakit. Hal ini dikarenakan tanaman ini memiliki kandungan antioksidan tinggi dan sebagai antibakteri dan antivirus. Penyakit Vibriosis yang disebabkan oleh bakteri Vibrio harveyi merupakan salah satu masalah serius pada budidaya laut dan payau yang dapat mengakibatkan kematian pada ikan dan udang yang dibudidayakan baik di air laut maupun payau. Penelitian ini bertujuan untuk mengetahui potensi penggunaan ekstrak daun Binahong (Anredera cordifolia) dengan konsentrasi yang berbeda sebagai penghambat pertumbuhan bakteri Vibrio harveyi secara in-vitro. Metode yang digunakan adalah dengan melakukan uji Minimun Inhibitory concentration (MIC) untuk mengetahui kadar minimal menghambat pertumbuhan Vibrio harveyi dan Minimum Bactericidal Concentration (MBC) dengan menggunakan kertas cakram. Hasil penelitian menunjukkan penggunaan ekstrak daun Binahong (Anredera cordifolia) dengan konsentrasi yang berbeda memberikan pengaruh yang nyata terhadap pertumbuhan bakteri Vibrio harveyi secara in vitro. Ekstrak daun Binahong (Anredera cordifolia) dengan konsentrasi 3\%, 5\%,7\%,9\%,11\% dan 13\% hanya bersifat bakteriostatik yaitu menghambat pertumbuhan bakteri Vibrio harveyi dengan konsentrasi terbaik yang didapatkan yaitu sebesar $13 \%$.
\end{abstract}

Kata Kunci: daun Binahong; Vibrio harveyi; daya hambat

\section{Pendahuluan}

Penyakit dapat didefinisikan sebagai segala sesuatu yang dapat menimbulkan gangguan suatu fungsi atau struktur dari alat tubuh atau sebagian alat tubuh, baik secara langsung maupun tidak langsung (Kordi, 2004). Menurut Handajani dan Samsundari (2005), penyakit yang menyerang tidak datang begitu saja, melainkan melalui proses hubungan antara tiga faktor, yaitu kondisi lingkungan (kondisi dalam air), kondisi inang, dan adanya jasad patogen (jasad penyakit).

Penurunan kualitas perairan pada lokasi budidaya dapat menyebabkan terjadinya serangan penyakit. Salah satu penyakit pada ikan atau udang yang sering menyerang lokasi budidaya adalah penyakit Vibriosis. Vibriosis terjadi secara berkala di dunia dan dapat menyebabkan kematian massal pada beberapa spesies ikan (Austin and Austin, 1993). Salah satu penyebab serangan penyakit Vibriosis adalah bakteri bercahaya (luminous bacteria) yaitu bakteri Vibrio harveyi (Kraxberger-Beatty et al., 1990). Strains Vibrio adalah bakteri dominan di air laut dan umumnya menginfeksi udang budidaya maupun udang liar (Hervio - Heath et al., 2002). Bakteri ini penyebab penyakit pada udang yang mampu menyerang bagian-bagian tubuh udang baik di luar maupun di dalam tubuh.

Dalam menanggulangi penyakit ini pengelola panti benih pada umumnya menggunakan antibiotik untuk 
menanggulangi bakteri bercahaya (Vibrio harveyi) tetapi dalam penggunaannnya sering tidak terkontrol sehingga hasil yang diperoleh tidak efektif dan penambahan antibiotik kedalam perairan tambak akan menimbulkan kekebalan (Izzati, 2007). Disamping itu, kandungan antibiotik pada komoditas udang menyebabkan jatuhnya harga udang di pasaran internasional, penggunaan antibiotik dapat menimbulkan masalah residu obat pada udang sehingga berdampak pada penolakan pasar udang tersebut karena membahayakan kosumen (Prajitno, 2007).

Penanggulangan penyakit yang disebabkan Vibrio harveyi dapat menggunakan bahan kimia dan antibiotik. Namun, penggunaan bahan tersebut secara terus-menerus dengan dosis yang kurang tepat telah mengakibatkan Vibrio harveyi menjadi resisten (Saptiani dan Hartini, 2008) Populasi bakteri Vibrio harveyi di lingkungan pemeliharaan udang dapat ditekan dengan cara penggunaan bahan obat-obatan alami seperti Binahong. Dengan penggunaan bahan alami dampak resistensi bakteri terhadap antibiotik dapat diminimalkan, sehingga lebih aman bagi udang. Secara turun-temurun, tanaman Binahong dipercaya memiliki beragam khasiat pengobatan mulai dari penyakit ringan hingga penyakit berat, diantaranya merupakan penyakit yang disebabkan oleh mikroorganisme. Namun, hingga kini belum ada penelitian khusus yang menunjukkan kebenaran khasiat tanaman tersebut, baik dengan uji preklinis maupun klinis. Berdasarkan informasi tersebut maka perlu dilakukan penelitian potensi ekstrak daun Binahong sebagai penghambat pertumbuhan Vibrio harveyi.

\section{Materi dan Metode Penelitian}

Penelitian dilakukan di Laboratorium Parasit dan Penyakit Ikan, Fakultas Perikanan dan Kelautan Universitas Brawijaya. Bahan penelitian yang digunakan adalah isolat bakteri Vibrio harveyi, daun Binahong, Nutrient Broth (NB), Nutrient Agar (NA), Thiosulphate-Citrate-Bile Salts-Sucrose Agar (TCBSA), McFarland 1, dan aquades steril. Peralatan penelitian yang digunakan meliputi tabung reaksi, cawan petri, rak tabung, pembakar Bunsen, ose, pinset, mikroskop, pipet Pasteur, pipet tetes, pipet ukur, neraca timbangan, inkubator, spektrofotometer, rotary vacum evaporator, pengaduk, erlenmeyer, autoclave, mikrofilter, centrifuge, spidol marker, gelas obyek, gelas cover, vortex, dan jangka sorong. Rancangan percobaan menggunakan Rancangan Acak Lengkap (RAL) yang terdiri dari 6 perlakuan dengan 3 kali ulangan. Penelitian ini menggunakan metode pengenceran (dilution methods) melalui penentuan Minimum Inhibitory Concentration (MIC) Test dan Minimum Bactericidal Concentration (MBC) Test (Baron et al., 1994).

\subsection{Ektraksi Daun Binahong}

Metode ekstraksi menggunakan metode ekstraksi dari Taie et al. (2013), dengan sedikit modifikasi. Sampel Binahong dikeringkan selama 48 jam dengan menggunakan oven pada suhu $50^{\circ} \mathrm{C}$. Setelah dikeringkan, $100 \mathrm{~g}$ sampel kering dimaserasi ke dalam $1000 \mathrm{ml}$ air aquades pada suhu $80^{\circ} \mathrm{C}$ selama 15 menit. Selanjutnya sampel ekstrak didinginkan dan diendapkan pada suhu ruang selama 24 jam, kemudian disaring dengan menggunakan kertas saring (Whatman No. 1). Sampel ekstrak yang sudah disaring disimpan pada suhu $20^{\circ} \mathrm{C}$ untuk penggunaan selanjutnya. Langkah berikutnya hasil saringan yang telah didapat dibuat 6 macam konsentrasi yaitu $3 \%, \quad 5 \%, 7 \%, 9 \%, \quad 11 \%$ dan $13 \%$ dengan menggunakan $\mathrm{NaCl}$ fisiologis sebagai pengencer.

\subsection{Uji Aktivitas Antibakteri}

Langkah awal yang dilakukan untuk penentuan metode MIC (Minimum Inhibitory Concentration) yaitu penyiapan 13 tabung reaksi steril dan dimasukkan 4,5 ml medium NB ke dalam masing-masing tabung reaksi. Ekstrak daun Binahong dengan berbagai konsentrasi (1\%, 2\%, 3\%, 4\%, $5 \%, 10 \%, 15 \%, 20 \%, 25 \%, 30 \%, 35 \%$, Kontrol 1 (K1) dan Kontrol 2 (K2)) dimasukkan sebanyak 0,5 ml ke dalam masing-masing tabung reaksi. Kemudian ditambahkan suspensi bakteri Vibrio harveyi (standar 0,5 McFarland) sebanyak $0,25 \mathrm{ml}$ dan divortek hingga homogen. Diinkubasi pada suhu ruang selama 24 jam (Boyd, 1995). Hasil pengamatan dibandingkan dengan larutan pambanding (medium NA ditambahkan konsentrasi ekstrak tanpa suspensi bakteri dan medium NA dengan suspesi bakteri) sehingga dapat diketahui adanya media yang mulai bening/jernih yang menunjukkan nilai MIC.

Selanjutnya dilakukan uji Minimum Bactericidal Concentration (MBC) metode Kirby-Bauer (Koneman, et al, 1988) yaitu dengan menggunakan kertas cakram. Biakan bakteri Vibrio harveyi dipindahkan secara aseptik sebanyak $3 \mathrm{~mL}$ dari medium NB ke cawan petri steril yang telah berisi medium TCBSA yang masih cair, lalu digoyang secara perlahan-lahan sampai suspensi TCBSA. tersebar secara merata. Setelah medium memadat, kertas cakram masing masing dimasukan ke dalam konsentrasi ekstrak daun ketapang yang telah dibuat yaitu 3\%, 5\%, $7 \%$, 9\%, 11\%, 13, dan tanpa perlakuan sebagai kontrol. Kertas cakram yang telah direndam pada ektrak daun Binahong sesuai konsetrasi kemudian diangkat menggunakan pinset steril dan dipindahkan secara aseptik pada permukaan medium TCBSA yang telah memadat, selanjutnya diinkubasi pada suhu $40^{\circ} \mathrm{C}$, dan dilakukan pengamatan 24 jam dan 48 jam. Pengujian daya hambat ekstrak daun Binahong terhadap bakteri Vibrio harveyi. dilakukan sebanyak 3 kali pengulangan. Zona bening yang terbentuk setelah masa inkubasi diukur dengan menggunakan jangka sorong.

\subsection{Analisa Data}

Data hasil penelitian uji MBC secara kuantitatif yaitu nilai diameter zona bening yang dihasilkan dianalisis dengan analisis varian (ANAVA). Apabila perlakuan yang diberikan menunjukkan pengaruh yang nyata, maka ekstrak daun Binahong memberikan pengaruh yang nyata terhadap pertumbuhan bakteri Vibrio harveyi secara in vitro (Kusriningrum, 1989).

\section{Hasil dan Pembahasan}

Berdasarkan hasil pengamatan selama penelitian, bakteri Vibrio harveyi yang tumbuh pada media padat TCBSA 
secara visual membentuk koloni berwarna kuning dan bentuk koloni membulat dengan permukaan cembung (Gambar 1). Sesuai pendapat Bonang dan Koeswardono (1982) yang menyebutkan bahwa kuman ini akan membentuk koloni yang berwarna kuning muda pada pembenihan TCBSA. Hal ini berkaitan dengan kemampuan Vibrio harveyi untuk memanfaatkan sukrosa. Bakteri Vibrio harveyi yang tumbuh pada media TCBSA membentuk koloni dengan warna kuning. Vibrio harveyi yang tidak mampu mensintesa sukrosa, koloninya tetap akan berwarna hijau (Sumargono, 2004).

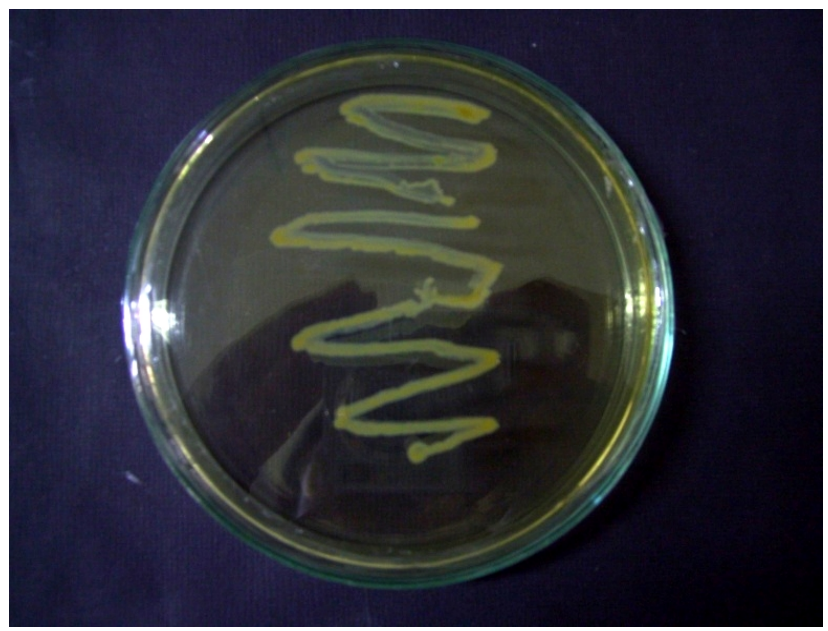

Gambar 1. Koloni Bakteri Vibrio harveyi

Uji MIC merupakan suatu cara untuk menentukan konsentrasi terendah dari bahan-bahan yang digunakan sebagai obat (ekstrak meniran) sehingga dapat menghambat pertumbuhan mikroorganisme (Vibrio harveyi) secara secara makroskopis sehingga bisa dilihat secara visual (Samsundari, 2006; Soleha, 2015). Hasil uji kadar hambat minimal (MIC) diperoleh bahwa kadar hambat minimal ekstrak daun Binahong (Anredera cordifolia) terhadap pertumbuhan bakteri Vibrio harveyi adalah 3\%. Sedangkan pada konsentrasi $1 \%$ dan $2 \%$ belum mampu menghambat pertumbuhan bakteri Vibrio harveyi. Pada konsentrasi 3\% jumlah bakteri berkurang (hasil biakan pada tabung reaksi mulai tampak jernih) setelah masa inkubasi selama 24 jam pada suhu $35^{\circ} \mathrm{C}$, hal ini ditandai dengan penurunan derajat kekeruhan apabila dibandingkan dengan kontrol (media dan bakteri) (Tabel 1). Perubahan warna jernih hal ini menunjukkan bakteri tidak terhambat. Perubahan warna pada uji MIC tidak dapat dijadikan patokkan terhambat atau tidaknya bakteri karena hanya merupakan uji awal oleh karena itu perlu dilanjutkan dengan uji Minimum Bactericidal Concentration (MBC).

Pemeriksaan uji Minimum Bactericidal Concentration (MBC) ekstrak daun Binahong (Anredera cordifolia) dengan metode cakram menunjukkan bahwa ekstrak daun Binahong mampu sebagai penghambat pertumbuhan bakteri Vibrio harveyi, hal ini dapat dijelaskan dengan adanya daerah berwana bening di sekitar kertas cakram yang merupakan daerah hambatan bakteri Vibrio harveyi. Daerah zona bening menunjukkan pada zona ini bakteri Vibrio harveyi tidak dapat tumbuh dan berkembang. Pada kertas cakam control tidak terbentuk zona bening karena tidak terdapat zat anti bakteri yang dapat menghambat pertumbuhan bakteri Vibrio harveyi.

Tabel 1

Kadar Hambat Minimal MIC Ekstrak Daun Binahong (Anredera cordifolia) Terhadap Bakteri Vibrio harveyi

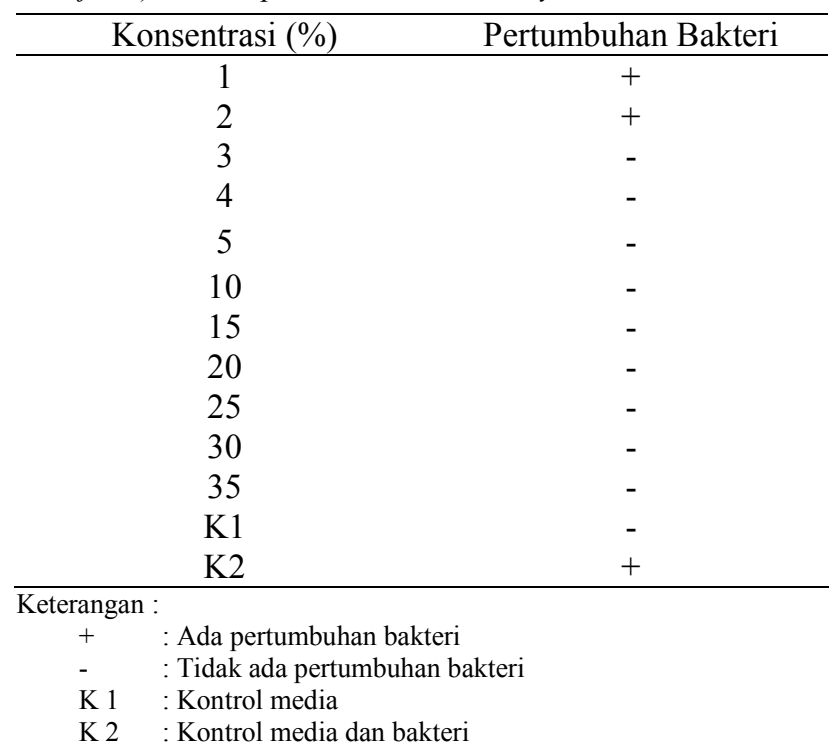

Kepekaan bakteri terhadap zat antibakteri dapat diketahui dari diameter daerah hambatan yang terbentuk pada uji cakram. Luas wilayah jernih merupakan petunjuk kepekaan mikroorganisme terhadap antibakteri. Berdasarkan hasil yang diperoleh, diameter daerah hambat (daerah yang tidak ditumbuhi bakteri) yang terbentuk bervariasi pada masing-masing perlakuan. Hasil diameter daerah hambat hasil uji cakram yang terbentuk dapat dilihat pada Tabel 2, sedangkan gambaran uji cakram ekstrak daun Binahong dengan konsentrasi berbeda-beda ditampilkan pada Gambar 2.

Tabel 2

Hasil Diameter Hambatan Ekstrak Daun Binahong (Anredera cordifolia) Terhadap Vibrio harveyi

\begin{tabular}{|c|c|c|c|c|c|}
\hline \multirow{2}{*}{$\begin{array}{c}\text { Perlakuan } \\
(\%)\end{array}$} & \multicolumn{3}{|c|}{ Diameter Daerah Hambatan (mm) } & \multirow{2}{*}{ Total } & \multirow{2}{*}{ Rata-rata } \\
\hline & Ulangan 1 & Ulangan 2 & Ulangan 3 & & \\
\hline 3 & 6,4 & 7,7 & 7,5 & 21,6 & 7.20 \\
\hline 5 & 8,4 & 9,3 & 7.7 & 25.4 & 8.47 \\
\hline 7 & 9,3 & 9,7 & 10.1 & 29.1 & 9.70 \\
\hline 9 & 10,5 & 10,9 & 8,2 & 29.6 & 9.87 \\
\hline 11 & 9,9 & 10,3 & 9.5 & 29.7 & 9.90 \\
\hline 13 & 10,5 & 10,9 & 9.4 & 30.8 & 10.3 \\
\hline \multirow[t]{2}{*}{ Kontrol $(0)$} & 0,0 & 0,0 & 0,0 & 0,0 & 0,0 \\
\hline & & & $\sum=$ & 166,2 & \\
\hline
\end{tabular}

Hasil tersebut menunjukkan bahwa semakin besar konsentrasi ekstrak daun Binahong didapatkan diameter hambatan yang semakin besar. Hal ini disebabkan semakin tinggi konsentrasi dari perlakuan yang diberikan maka jumlah senyawa antibakteri yang terkadung akan semakin tinggi kadarnya. jumlah senyawa antibakteri semakin tinggi, maka daya hambat terhadap bakteri juga akan semakin tinggi. Hal ini sesuai dengan pernyataan 
Sudewo (2007), yang mengatakan bahwa tumbuh atau tidaknya bakteri pada setiap konsentrasi dapat disebabkan karena pada setiap konsentrasi mengandung kadar antibakteri yang berbeda, semakin encer pada uji MIC jumlah pelarut lebih besar daripada jumlah ekstrak tanaman.

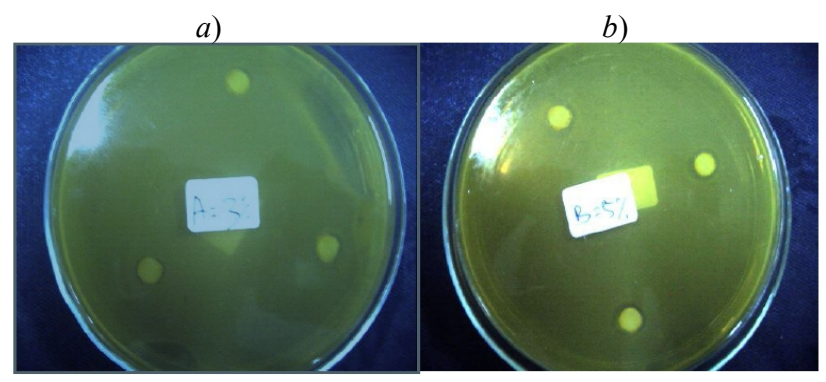

Konsentrasi 3\%

c)

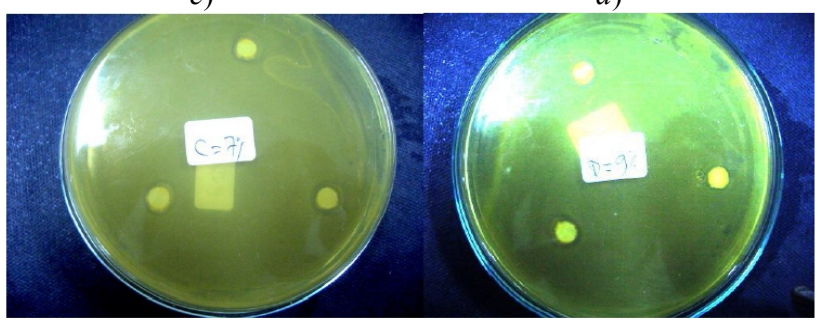

Konsentrasi $7 \%$

e)

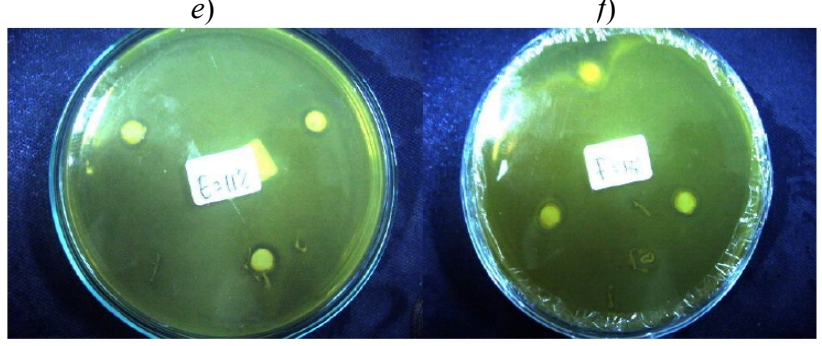

Konsentrasi $11 \%$
Gambar 2. Hasil uji cakram ekstrak daun Binahong dengan konsentrasi; (a) 3\%; (b) 5\%; (c) 7\%; (d) 9\%; (e) 11\%; dan (f) $13 \%$.

Selanjutnya untuk mengetahui pengaruh pemberian konsentrasi ekstrak daun Binahong yang berbeda terhadap pertumbuhan bakteri Vibrio harveyi maka dilakukan analisis keragaman dengan hasil seperti yang ditunjukkan pada Tabel 3 .

\section{Tabel 3}

Analisa Keragaman/Sidik Ragam daya hambat Ekstrak Daun Binahong (Anredera cordifolia) Terhadap Bakteri Vibrio harveyi

\begin{tabular}{lrrrrrr}
\hline $\begin{array}{c}\text { Sumber } \\
\text { keragaman }\end{array}$ & Db & JK & KT & F Hitung & $\begin{array}{c}\text { F } \\
5 \%\end{array}$ & $\begin{array}{c}\text { F } \\
1 \%\end{array}$ \\
\hline Perlakuan & 5 & 20.6 & 4,1 & $5,902 * *$ & 3,1 & 5,06 \\
Acak & 12 & 8.36 & 0,7 & & & \\
Total & 17 & & & & & \\
\hline
\end{tabular}

Berdasarkan hasil analisa keragaman menunjukkan bahwa pemberian ekstrak daun Binahong dengan konsentrasi yang berbeda berpengaruh sangat nyata terhadap pertumbuhan bakteri Vibrio harveyi. Hal ini membuktikan bahwa ekstrak daun Binahong dapat menghambat pertumbuhan bakteri Vibrio harveyi secara in vitro. Hasil penelitian ini didukung penelitian sebelumnya oleh Khunaifi (2010) dan Rimporok dkk. (2015) yang menyatakan bahwa semakin tinggi konsentrasi ekstrak daun Binahong yang diberikan, maka akan semakin besar kemampuan menghambat pertumbuhan bakteri-bakteri seperti Staphylococcus aureus, Pseudomonas aeruginosa, dan Streptococcus mutans.

Daun Binahong memiliki kemampuan sebagai antibakteri dan antimikroba. Hal ini disebabkan karena dalam daun Binahong terdapat senyawa aktif yaitu flavonoid, alkanoid, terpenoid dan saponin. Flavonoid merupakan zat yang terbesar yang yang dapat berperan langsung sebagai antioksidan dan antibakteri (Darsana dkk., 2013). Kemampuan ektrak daun Binahong dalam menghambat pertumbuhan bakteri Vibrio harveyi ditandai dengan terbentuknya zona bening di sekitar kertas cakram. hal ini dapat terjadi karena didalam ektrak daun Binahong terdapat kandungan senyawa flavonoid. Mekanisme senyawa aktif dalam ekstrak daun Binahong dengan penghambatan pertumbuhan mikroorganisme dapat dilakukan melalui penghambatan sintesis dinding sel, penghambatan fungsi membran sel, penghambatan sintesis protein dan penghambatan pertumbuhan sel bakteri (Robinson, 1995).

Polifenol mempunyai komposisi sama dengan flavonoid yang merupakan senyawa fenol dan bersifat sebagai koagulator protein. Senyawa flavonoid memiliki kemampuan membentuk kompleks dengan protein sel bakteri melalui ikatan hidrogen. Ikatan hidrogen dan flavonoid menyebabkan struktur dinding sel dan membran sel bakteri menjadi tidak stabil dan mengakibatkan sel lisis (Harborne, 1987). Hal lain sebagai penyebab Terhambatnya pertumbuhan bakteri Vibrio harveyi karena senyawa flavonoid dalam ekstrak daun Binahong mengganggu proses fisiologis dalam bakteri dengan cara menghambat pembentukan biofilm pada Vibrio harveyi yang digunakan untuk perlindungan diri dalam suatu koloni dan mengambat pembentukan Type Three Secretion System (TTSS) (Vikram et al., 2010). Biofilm dihasilkan oleh bakteri sebagai salah satu upaya untuk melakukan proses adaptasi dengan cara menempel pada suatu permukaan, berkoloni dan menyelubungi dirinya sehingga berperan sebagai metode perlindungan diri (Buana dan Wardani, 2013).

Saponin merupakan senyawa aktif permukaan yang kuat yang menimbulkan busa jika dikocok dalam air (Hostettmann and Marston, 1995). Saponin akan mengubah tegangan muka dan mengikat lipid pada sel bakteri yang menyebabkan lipid terekskresi dari dinding sel sehingga permeabilitas membran bakteri terganggu. Alkaloid dapat menggangu komponen penyusun peptidoglikan pada sel bakteri, sehingga lapisan dinding sel tidak terbentuk secara utuh dan menyebabkan kematian sel tersebut (Robinson, 1995).

Perbedaan diameter zona bening pada masing- masing perlakuan dipengaruhi oleh beberapa faktor sehingga zat 
antti bakteri dapat bekerja dengan baik. Faktor-faktor tersebut antara lain adalah konsentrasi zat antibakteri, jumlah bakteri, jenis bakteri, dan suhu (Pelczar dan Chan, 1986).

\section{Simpulan}

Berdasarkan hasil penelitian dapat disimpulkan bahwa Ekstrak daun Binahong memiliki potensi menghambat pertumbuhan bakteri Vibrio harveyi secara invitro. Daya hambat pertumbuhan bakteri Vibrio harveyi akan semakin luas seiring dengan peningkatan laju konsetrasi ekstrak daun Binahong yang diberikan, dengan konsentrasi perlakuan terbaik yang didaptkan sebesar 13\%. Dari penelitian ini menunjukkan bahwa daun Binahong dapat dijadikan sebagai sumber potensial yang mengandung senyawa aktif antibakteri, sehingga dapat digunakan sebagai bahan pengobatan alternatif dalam pengendalian penyakit bakteri laut dan payau, khususnya Vibrio harveyi.

Perlu dilakukan penelitian lebih lanjut untuk mengetahui konsetrasi terbaik dalam menghambat pertumbuhan bakteri Vibrio harveyi menggunakan ekstrak daun Binahong. Serta perlu dilakukan penelitian secara pengunakan ekstrak daun Binahong secara invivo.

\section{Daftar Pustaka}

Austin, B., \& Austin, D. A. (1993). Bacterial fish pathogens: disease of farmed and wild fish. (2nd ed.). Chichester, UK: Springer in association with Praxis Publishing.

Baron, E.J., Peterson, L.R., \& Finegold, S.M. (Eds) (1994). Bailey and Scott's Diagnostic Microbiology, 9th ed. St. Louis, Missouri, US: Mosby.

Bonang, G., \& Koeswardono, E.S. (1982). Mikrobiologi kedokteran: untuk laboratorium dan klinik. Jakarta, Indonesia: Gramedia.

Buana, E.O.G.H.N., \& Wardani, A.K. (2013). Isolasi Bakteriofag Litik Sebagai Agen Biosanitas Pada Proses Pelisisan Bakteri Pembentuk Biofilm. Jurnal Pangan dan Agroindustri, 2(2), 36-42.

Darsana, I.G.O., Besung, I.N.K., \& Mahatmi, H. (2012). Potensi daun Binahong (Anredera cordifolia (Tenore) Steenis) dalam menghambat pertumbuhan bakteri Escherichia Coli secara In vitro. Indonesia Medicus Veterinus, 1(3), 337-351.

Handajani, H., \& Samsundari, S. (2005). Parasit dan Penyakit Ikan. Malang, Jawa Timur, Indonesia: UMM Press.

Harborne, J.B. (1987) Metode fitokimia : penuntun cara modern menganalisis tumbuhan. Diterjemahkan oleh Padmawinata, K., \& Soediro, I. Bandung, Indonesia: ITB Press.

Hervio - Heath, D., Colwell, R.R., Derrien, A., Rober-Pillot, A., Fournier, J.M., \& Pommepuy, M. (2002). Occurrence of pathogenic vibrios in coastal areas of France. Journal of applied microbiology, 92(6), 1123-1135.

Hostettmann, K., \& Marston, A. (1995). Saponins. New York, US: Cambridge University Press.
Izzati, M. (2007). Skreening potensi antibakteri pada beberapa spesies rumput laut terhadap bakteri patogen pada udang windu. BIOMA, 9(2), 62-67.

Khunaifi, M. (2010). Uji Aktivitas Antibakteri Ekstrak Daun Binahong (Anredera cordifolia (Ten.) Steenis) Terhadap Bakteri Staphylococcus aureus dan Pseudomonas aeruginosa. Skripsi. Malang, Jawa Timur, Indonesia: Jurusan Biologi Fakultas Sains Dan Teknologi, Universitas Islam Negeri (UIN) Maulana Malik Ibrahim.

Koneman, E.W., Allen, S.D., Dowell, V.R., Jr., Janda, W.M., Sommers, H.M. and Winn, W.C., Jr. (1988). Color Atlas and Textbook of Diagnostic Microbiology, 3rd ed. Philadelphia, Pennsylvania-US: JB Lippincott \& Company.

Kordi, M.G.H. (2004). Penanggulangan hama dan penyakit ikan. Jakarta, Indonesia: PT Rineka Cipta dan PT Bina Adikarsa.

Kraxberger-Beatty, T., McGarey, D.J., Grier, H.J., \& Lim, D.V. (1990). Vibrio harveyi, an opportunistic pathogen of common snook, Centropomus undecimalis (Bloch), held in captivity. Journal of Fish Diseases, 13(6), 557-560.

Kusriningrum, R. (1989). Dasar Perancangan Percobaan dan Rancangan Acak Lengkap. Surabaya, Indonesia: Fakultas Kedokteran Hewan Universitas Airlangga.

Pelczar, M.J., Jr., \& Chan, E.C.S. (1986). Dasar-Dasar Mikrobiologi Jilid 1. Diterjemahkan oleh Hadioetomo, R.S., Imas, T., Tjitrosomo, S.S., \& Angka, S.L. Jakarta, Indonesia. UI Press.

Prajitno, A. (2007). Penyakit Ikan-Udang: Bakteri. Malang, Jawa Timur, Indonesia: UM Press.

Rimporok, S., Kepel, B.J., \& Siagian, K.V. (2015). Uji efektivitas ekstrak daun Binahon (Anredera cordifolia Steenis) terhadap pertumbuhan Streptococcus mutans secara in vitro. Pharmacon, 4(4), 15-21.

Robinson, T. (1995). Kandungan Organik Tumbuhan Tingkat Tinggi. Diterjemahkan oleh Padmawinata, K. Bandung, Indonesia: ITB Press.

Samsundari, S. (2006). Penggunaan bahan obat alami terhadap resistensi bakteri Aeromonas hydrophilla yang menyerang Ikan Mas (Cyprinus carpio). Jurnal Gamma, 2(1), 71-83.

Saptiani, G. \& Hartini. (2008). Daya hambat dan daya lindung ekstrak daun sirih (Piper bettle L) terhadap bakteri Vibrio harveyi secara in vitro dan in vivo pada post larva udang windu (Penaeus monodon F.). Makalah dipresentasikan pada Indonesian Aquaculture (Indoaqua) 2008. YogyakartaIndonesia, 17-20 November, 2008.

Soleha, T.U. (2015). Uji Kepekaan terhadap Antibiotik. Jurnal Kedokteran Universitas Lampung, 5(9), 119-123.

Sudewo, B. (2010). Basmi penyakit dengan sirih merah (Revisi). Yogyakarta, Indonesia: AgroMedia Pustaka.

Taie, H.A., Helal, M.M.I., Helmy, W.A., \& Amer, H. (2013). Chemical composition and biological potentials of aqueous extracts of fennel (Foeniculum vulgare L). Journal of Applied Sciences Research, 9(3), 1759-1767.

Vikram, A., Jayaprakasha, G. K., Jesudhasan, P. R., Pillai, S. D., \& Patil, B. S. (2010). Suppression of bacterial cell-cell signalling, biofilm formation and type III secretion system by citrus flavonoids. Journal of applied microbiology, 109(2), 515-527.

(C) 2016 by the authors; licensee Udayana University, Indonesia. This article is an open access article distributed under the terms and conditions of the Creative Commons Attribution license (http://creativecommons.org/licenses/by/3.0/). 